\title{
Az Európai Újraélesztési Társaság (ERC) 2021. évi, az emeltszintü újraélesztésről (ALS) és periarrest ritmuszavarok ellátásáról szóló ajánlásának összefoglaló bemutatása
}

\author{
Tóth Balázs, Pandur Attila, \\ Pécsi Tudományegyetem Egészségtudományi Kar, Sürgősségi Ellátási és Egészségpedagógiai Intézet, \\ Oxyológiai, Sürgősségi Ellátási Tanszék, Pécsi Tudományegyetem Egészségtudományi Doktori Iskola \\ Prof. Dr. Betlehem József, \\ Pécsi Tudományegyetem Egészségtudományi Kar, Sürgősségi Ellátási és Egészségpedagógiai Intézet \\ Tóth Balázs szakoktató \\ Kapcsolattartó szerző \\ Priskin Gábor, Schiszler Bence, Dr. Radnai Balázs, \\ Pécsi Tudományegyetem Egészségtudományi Kar, Sürgősségi Ellátási és Egészségpedagógiai Intézet, \\ Oxyológiai, Sürgősségi Ellátási Tanszék
}

Jelen referátum célja az Európai Újraélesztési Társaság (European Resuscitation Council, ERC) 2021-ben megjelent(1), a periarrest időszak ellátását is magában foglaló emelt szintű újraélesztési protokolljának összefoglaló bemutatása, hangsúlyozva a korábbi, 2015-ben kiadott protokoll(2) ajánlásaitól való eltéréseket.

Az életet veszélyeztető ritmuszavarok azonnali azonosítása és kezelése alapvető jelentőségű a keringésmegállás megelőzésében, illetve ismétlődésének elkerülése érdekében. A 2021-ben, az ERC által kiadott protokoll igazán jelentős változást a periarrest tachycard ritmuszavarok ellátási algoritmusában hozott. Az ellátás fóbb terápiás vonala, a korábbi guideline-nal megegyezően, továbbra is a beteg állapotának stabilitása/instabilitása alapján kerül felosztásra.

Az emelt szintű újraélesztés (Advanced Life Support ALS) többlet beavatkozásokkal kiterjesztett alapszintü újraélesztés (Basic Life Support - BLS). Az ajánlás részletesen taglalja a kórházon belüli és kívüli keringésmegállást, az ezek ellátási lépéseit tartalmazó ALS algoritmust, a kardiopulmonáris reszuszcitáció (CPR) során végzett légútbiztosítást, gyógyszeres terápiát és annak menedzselését. Ezen irányelvek a Nemzetközi Reszuszcitációs Bizottság (International Liaison Committee on Resuscitation - ILCOR ) által meghatározott ellátási renden alapulnak(3).

\section{Emelt szintü újraélesztés (Advanced life support - ALS)}

A szerzők külön kiemeltek úgynevezett 5 fö üzenetet, amelyek összefoglalják az ALS során megfogalmazható legfontosabb célokat.

a) Legfontosabb elemek továbbra is a magas minőségü mellkaskompressziók minimális megszakításokkal, a korai defibrilláció és a reverzibilis okok ellátása. b) A keringésmegállás legtöbbször megelőzhető a prearrest időszakban jelentkező premonitorikus tünetek megfigyelésével, akár intra-, akár extrahospitálisan. 
c) Csak az abban gyakorlott ellátók végezzenek endotracheális intubációt - használjunk egyszerű eszköz nélküli vagy eszközös légútbiztosítási technikákat.

d) Nem sokkolandó ritmus esetén minél hamarabb adjunk adrenalint.

e) Kiemelt betegcsoportok esetén gondoljunk az eCPR alkalmazására, ha a hagyományos ALS hatástalannak bizonyul.

A beteg elsődleges vizsgálatát a már az alapszintű újraélesztésben ismertetett eszmélet- majd légzésvizsgálattal kezdjük. A „nem reagáló” állapothoz társuló és nem detektálható vagy elégtelen légzés esetén kezdjünk CPR-t 30:2 mellkaskompresszió:lélegeztetés arányban. Amennyiben professzionális ALS team elérhetö, értesítéséről szintén ebben a lépésben szükséges gondoskodni. Defibrillátor rendelkezésre állásakor azonnal végezzünk ritmuselemzést.

Az újraélesztési algoritmus választandó ágát továbbra is az iniciális ritmus sokkolandó (kamrafibrilláció (VF) és pulzus nélküli kamrai tachycardia (pnVT)) vagy nem sokkolandó (asystolia (ASYSTOLIA) vagy pulzus nélküli elektromos aktivitás (PEA)) volta határozza meg.

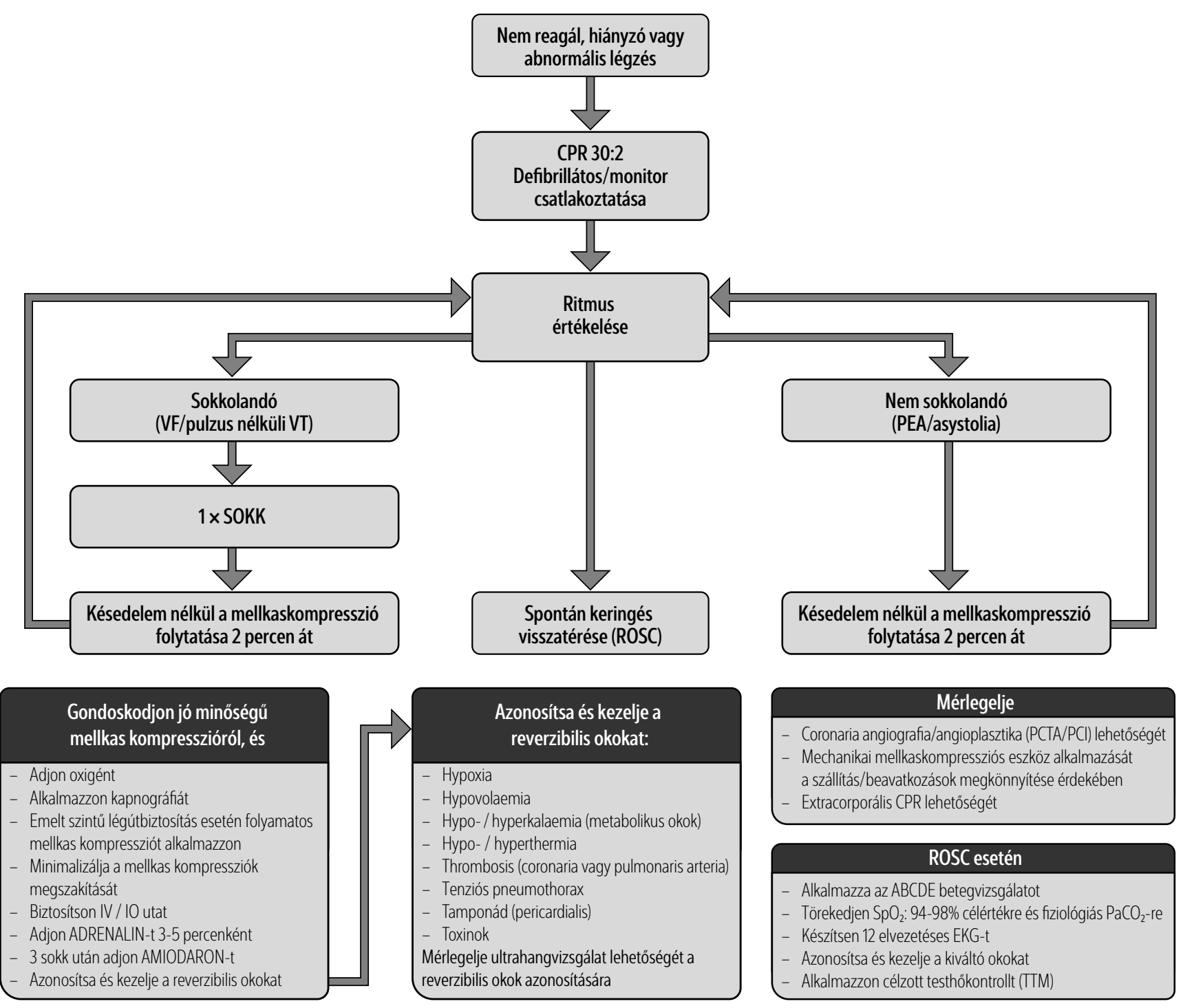

1. ábra: Az ALS algoritmusa 


\subsection{Sokkolandó ritmus (VF vagy pnVT)}

A sokkolandó ritmus felismerése ne vegyen igénybe több, mint 5 másodpercet, a minél rövidebb ideig tartó kompressziós szünet érdekében. A protokoll energiaválasztás tekintetében nem tartalmaz új ajánlásokat: továbbra is a bifázisos hullámforma a preferálandó, illetve amennyiben rendelkezésre állnak felragasztható elektródák, akkor azok választandók a lapátelektródák helyett (2). Alapvetően három fő hullámformát alkalmazhatunk a klinikai gyakorlatban, úgymint a csonka exponenciális bifázisos (BTE), az egyenes megközelítésű bifázisos (RLB) és a pulzáló bifázisos hullámformák (2). A kezdő energia értéke RLB esetében el kell, hogy érje a $120 \mathrm{~J}-t$, BTE esetében pedig a $150 \mathrm{~J}$-t. Ha az ellátó nem ismeri a használt készülék ajánlott energiaértékeit, akkor használja az elérhető legmagasabb energiaértéket. Az elektródák felhelyezése antero-laterális elrendezésben ajánlott. A jobb (sternális) elektróda a szegycsont jobb oldalára kerüljön, közvetlenül a kulcscsont alá. A bal (apikális) elektróda helye a bal oldali középső hónaljvonalban, megközelítőleg a V6-os EKG elektróda pozíciójában van. Amennyiben a sokkolandó ritmus a további ritmuselemzéseknél is fennáll, úgy emelkedő energiaértékekkel végezzük a defibrillációt. Fontos megjegyezni, hogy aszinkron defibrilláció esetén az elektródák felcserélhetőek. Amennyiben a mellkas szőrzete akadályt képez az eszközök felhelyezésében, akkor borotváljuk le az érintett testfelszínt.

Egyéb elfogadható alternatív elektróda pozíciók:

a) Bi-axilláris: A két elektróda a mellkas két laterális felszínén fekszik, egyik a jobb, másik a bal oldalon.

b) Az apikális elektróda standard pozícióban, az ellenoldali elektróda a hát jobb oldalán.

c) Az egyik elektróda a szív anatómiai vetületének megfelelően a mellkas elülső felszínén, a másik ennek tükörképeként a hát bal oldalán a lapocka csúcsa alatt.

Ha a beteg bármilyen beültetett eszközzel rendelkezik (pl.: ICD - beültetett kardioverter defibrillátor) akkor attól minimum $8 \mathrm{~cm}$ távolságba helyezzük el az elektródákat. A sokk leadását követően azonnal kezdjünk mellkaskompressziókat. Amennyiben nem elkülöníthető, hogy a ritmus aszisztólia vagy apró hullámú kamrafibrilláció, úgy folytassuk a CPR-t, ne defibrilláljunk! 2 percenként CPR-t követően ismételt ritmusanalízis következik. A harmadik sokk után
$300 \mathrm{mg}$ amiodaron intravénás adása mellett $1 \mathrm{mg}$ adrenalin bólus adását írja elő a protokoll. Az adrenalin 1 mg-onkénti adagolása 3-5 percenként folytatható, míg amiodaron-ból egyszer $150 \mathbf{~ m g}$ intravénás bólus ismételhető az ötödik sokk után. Bár az amiodaron az elsőként választandó antiarrhythmicum sokkolandó ritmussal járó keringésmegállás esetén, ám alternatív gyógyszerként, vagy amiodaron hiányában választható a lidocain is, a fentiekben az amiodaron-nál leírt esetekben intravénásan 100 mg kezdő, majd 50 mg ismétlő dózisban (4).

\subsection{Nem sokkolandó ritmus}

Amennyiben az azonosított ritmus PEA vagy ASYTOLE úgy intravénás, vagy intraosseális gyógyszerbejuttatási út elérhetősége mellett azonnali $1 \mathrm{mg}$ adrenalin adandó, majd folytassuk a CPR-t. Ezt a müveletet nem sokkolandó ritmus esetén 3-5 percenként ismételjük.

\subsection{Egyéb megfontolások}

\subsubsection{Oxigénterápia}

$\mathrm{Az}$ agy hypoxiás-ischaemiás sérülését elkerülendő továbbra is az elérhető legmagasabb áramlással adagolt oxigénterápia az ajánlott (3). A keringés spontán visszatérése és oxigénszaturáció illetve artériás parciális nyomásának mérhetővé válása esetén célzott, $\mathrm{SpO}_{2}=94-98 \%$ vagy $\mathrm{PaO}_{2}=75-100 \mathrm{Hgmm}$ érték elérése és fenntartása a cél (5).

\subsubsection{Lélegeztetés}

Emelt szintű kompetenciával rendelkező ellátónak, nem megfelelő légzés vagy légzésleállás esetén, a lehető legrövidebb időn belül mesterséges úton történő lélegeztetést kell kezdenie. A befúvásnak kb. 1 másodperc ideig kell tartania, olyan mennyiségű levegővel, ami már látható mellkaskitérést eredményez.

Bár korábban úgy gondolták, hogy a folyamatos mellkaskompresszió közben alkalmazott ballon-szelepmaszkos lélegeztetés nagyban növeli a gyomortartalom regurgitációjának esélyét, egy 23000 páciens bevonásával készült elővizsgálat nem mutatott statisztikai különbséget a lélegeztetési ciklus idejére felfüggesztett mellkaskompresszió és a folyamatos mellkaskompresszió melletti maszkos lélegeztetés túlélésre, vagy a halálozásra 
gyakorolt hatásában (6). Az ILCOR ajánlása alapján a fent említett beavatkozási módszerek mindegyike alkalmazható az ellátó választása szerint (7). Európai ellátásban jelenleg a 30:2 váltakozó ciklusú megközelítés a leggyakrabban használt módszer.

Amennyiben emelt szintű légútbiztosításra kerül sor, mind szupraglottikus légútbiztosító eszköz (SGA) használatakor, mind endotracheális intubációt követően 10/min frekvenciával kell megkezdeni a lélegeztetést. Mindkét esetben a folyamatosan végzett mellkaskompressziók mellett is végezhető a ventiláció. SGA esetében minimális levegőszivárgás tolerálható (figyelembe véve esetleges speciális körülményeket, például COVID-19 pandémia), ha azonban a szivárgás a lélegeztetés hatékonyságát rontja, úgy 30:2 arányú mellkaskompresszió/lélegeztetésre kell váltani.

\subsubsection{Légútbiztosítás}

A 2015-ben született ERC ajánlás a lépcsőzetes, az egyszerűbbtől a komplexebb beavatkozások irányába haladó légútbiztosító módszerek alkalmazását javasolta. Az azóta megszületett tudományos kutatási eredmények a következő ajánlások megfogalmazására késztették a szerzőket:

a) Használjunk ballon-szelep-maszkos lélegeztetést, vagy biztosítsunk emelt szintű légutat a CPR során

b) Amennyiben emeltszintü légút mellett döntünk, úgy a kórházon kívüli újraélesztéseknél SGA használatát javasolják az endotracheális intubációval (ETI) szemben, ha a beteg intubációja várhatóan nehéz lehet.

c) Amennyiben az intubáció várhatóan nem lesz nehezített, úgy SGA-t vagy ETI-t javasolják kórházon kívüli újraélesztés esetében.

Továbbra is javasolt a komplexitásában lépésenként emelkedő légútbiztosítási stratégia (8).

Eszközök tekintetében kiemelésre került, hogy az endotracheális intubáció több hátránnyal is rendelkezik a ballon-szelep-maszkos lélegeztetéssel szemben. Ilyenek a gyakori, felismerésre nem kerülö, nyelöcsőbe történő intubatio, elhúzódó kompressziós szünet ETI beavatkozás alatt, gyakori sikertelen intubáció, illetve az a tény, hogy az ETI egy komplex tudást és gyakorlatot igénylő beavatkozás, aminek kivitelezése majd fenntartása is bonyolult.
A videolaryngoscop egyre gyakrabban használt légútbiztosítási segédeszköz az anesztéziában és a kritikus állapotú betegek ellátásában (9),(10). A direkt laryngoscopiával összehasonlítva javítja az intubáció során a laryngeális régió képét, arányaiban több sikeres intubációt eredményez $(11,12)$, csökkenti az oesophagus intubáció esélyét (13), és rövidíti a kompresszió nélkül töltött időt (14). Fontos leszögezni, hogy napjainkban többféle ilyen típusú eszköz áll rendelkezésre, de ezek hatékonyságukban nem térnek el egymástól. A jelenlegi konszenzus azt tartja követendőnek, hogy a helyi protokollokban szabályozottak szerint, a beavatkozást végző ellátó dönthessen arról, hogy videolaryngoscopiát vagy direkt laryngoscopiát alkalmaz CPR közbeni légútbiztosítás során.

\subsubsection{Kapnográfia}

Jelen guideline az ILCOR frissített scoping review-ja (3) mely a témával foglalkozó legfrissebb szisztematikus összefoglaló közlemény(15), egy narratív review (16) és a korábbi, 2015-ös ERC protokoll (2) ajánlásain alapul. A kapnográfia folyamatos, non-invazív kilégzésvégi $\mathrm{CO}_{2}\left(\mathrm{EtCO}_{2}\right)$ mérést tesz lehetővé amely értéke közel azonos a parciális $\mathrm{CO}_{2}\left(\mathrm{pCO}_{2}\right)$ szinttel. A mérés trachea-intubált beteg esetében a legmegbízhatóbb, de szupraglottikus eszköz használat és ballonszelep-maszkos lélegeztetés mellett is értékelhető (17). A kapnometria/kapnográfia használata a következő okok miatt esszenciális:

a) Az endotracheális tubus helyes pozíciójának ellenörzése $(15,18)$

b) A CPR minőségének monitorizálása (19)

c) A keringés spontán visszatértének (ROSC) észlelése (20)

d) A CPR kimenetelének prognosztizálása $(15,21,22)$

\subsubsection{Reverzibilis okok}

Az ALS folyamatának fontos lépése a keringésmegállás reverzibilis okainak keresése, azok ellátása. Ezen okok bővebb kifejtését a reanimáció speciális körülményeit taglaló fejezet (23) foglalja magában, itt csak felsorolás szintjén kerül említésre:

- Hypoxia

- Hypovolaemia

- Hypo/hyperkalaemia (metabolikus okok)

- Hypo/hyperthermia

- Thrombosis (coronaria vagy pulmonaris arteria)

- Tensios pneumothorax 
- Tamponád (pericardialis)

- Toxinok

\subsubsection{Folyadékterápia}

Továbbra sem áll rendelkezésünkre olyan nagy elemszámú, kontrollált vizsgálat, amelyben az újraélesztés alatti folyadékpótlás hatásait vizsgálták. Az ajánlás továbbra is úgy fogalmaz, hogy amennyiben nem áll fenn bizonyított hypovolaemia, vagy folyadékhiány gyanúja, úgy rutinszerűen továbbra se adjunk nagy volumenủ folyadékot (2).

\subsubsection{Ultrasonographiás képalkotás ALS során}

Az ellátás helyszínén (point-of-care) ultrahangos képalkotás (POCUS) egy általánosan használt diagnosztikus eszköz a sürgősségi ellátásban, azonban a korábbi és az utóbbi időben megjelent szakirodalom is gyakorlott vizsgálóhoz kötik a használatát (2). A POCUS jól használható különböző reverzibilis okok beazonosítása során, mint például a perikardiális tamponád, vagy a tenziós pneumothorax (tPTX). A 2015-ben megjelent ERC ajánlás már a mellkaskompressziók végzése közben felvett subxyphoideális transzducer pozíciót javasol (2), hogy kompressziós szünetben azonnal vizsgálható legyen a beteg. Önmagában a jobb kamra dilatáció vizsgálata azonban nem alkalmas pulmonális embólia diagnosztizálására. A keringésmegállást követő pár percen belül jelentkezhet jobb kamra dilatáció, ahogy a szisztémás keringésből a vér a jobb kamrába tolul a nyomásgrádiens mentén (2426). Jelenleg korlátozottak az ismereteink a POCUS használhatóságáról CPR során, a mélyvénás trombózis azonosítása, tüdőembólia vagy pleura effúzió kimutatása, illetve FAST (Focussed Assessment with Sonography for Trauma) vizsgálat kivitelezése a has és az aorta sérülései esetében.

\subsubsection{Mechanikus mellkaskompressziós eszközök használata}

Nyolc nagy vizsgálat eredményeire alapozva a 2015-ös ajánlás nem ajánlotta a mechanikus mellkaskompressziós eszközök rutinszerű használatát (27-32), de megfelelő alternatívái lehetnek a jó minőségü manuális mellkaskompresszióknak, ha a körülmények nem ideálisak vagy az ellátót veszélyeztetik (pl. mellkaskompresszió szállítás során) $(2,18)$. A szerzők további meggyőző adat hiányában továbbra is a korábbi ajánlást tartják követendőnek (2).

\subsubsection{Extracorporális CPR (eCPR)}

$\mathrm{Az}$ extrakorporális CPR fogalmát az ELSO (Extracorporeal Life Support Organization) úgy fogalmazta meg, mint a konvencionális ALS ellenére hosszútávú spontán keringés fenntartására képtelen betegek esetében gyorsan telepíthető, veno-arteriális membrán oxigenátor (VA-ECMO) alkalmazása (33). $\mathrm{Az}$ ajánlás bizonyos esetekben, mikor a $\mathrm{CPR}$ nem hoz eredményt, javalja az eCPR alkalmazását.

\subsection{Intrahospitális ALS - 2. ábra}

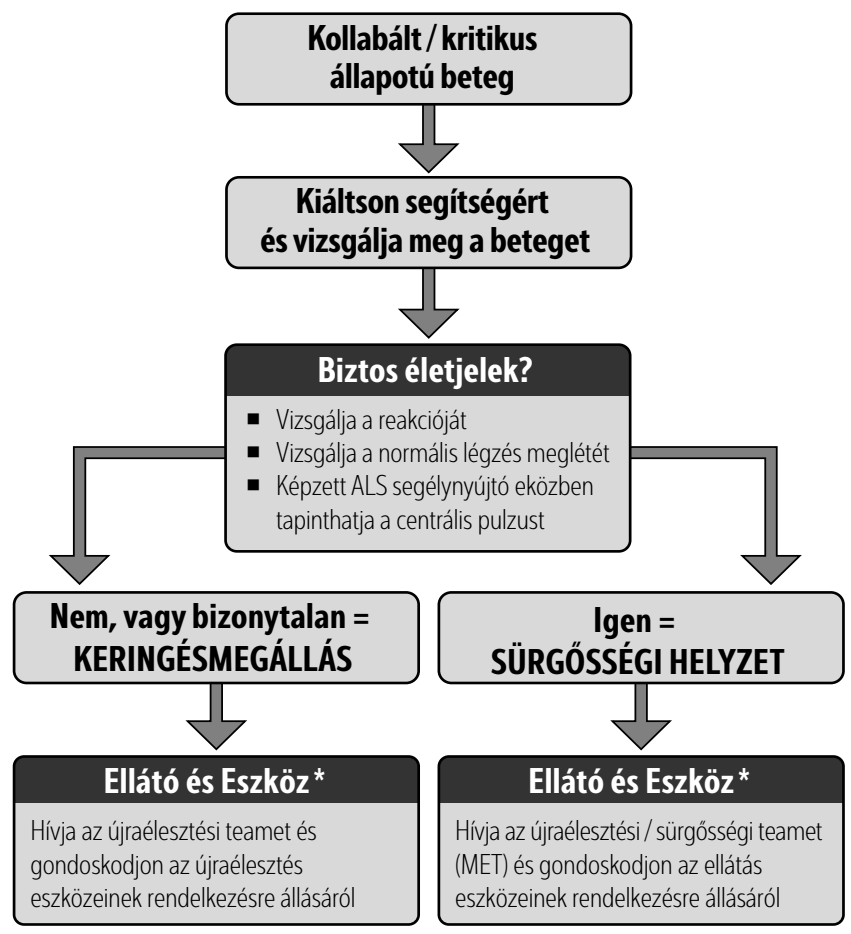

\section{Jó minőségü CPR *}

- Kezdjen jó minőségü CPR-t oxigén adásával és a légút biztosításával

- A mellkaskompressziót végző ellátót minden ritmusellenőrzéskor váltsa

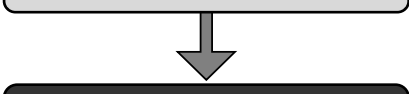

Defibrilláció *

Elektródák csatlakoztatása / AED bekapcsolása / sokk leadása utasítás esetén (Manuális defibrillátor használata, amennyiben rendelkezésre áll és képzett személy jelen van)

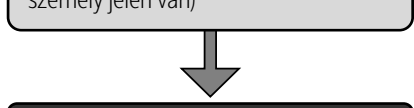

Emelt szintü újraélesztés Amennyiben elelgendö (ki)képzett személy jelen van

\section{Vizsgálat *}

- ABCDE vizsgálat: felismerni és kezelni

- Adjon magas áramlással oxigént (amint elérhető $\mathrm{SpO}_{2}$ titrálással)

- Monitorozza a beteget

- Biztosítson IV utat

- Ha még nem tette hívja az újraélesztési vagy sürgősségi teamet

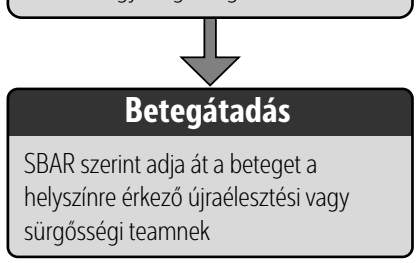
sürgösségi teamnek 
1.5 A keringésmegállás ellátásának princípiumai, mint a lehető legkorábbi defibrilláció, vagy a jó minőségü mellkaskompressziók, megegyeznek mind az kórházon kívüli, mind a kórházon belüli ALS esetében. A kórházi újraélesztés esetében az azonnal rendelkezésre álló klinikai szakdolgozók és eszközpark lehetővé teszik a keringésmegállás gyors felismerését és az iniciális terápia azonnali megkezdését. Érdemi változás itt sem történt a korábbi ajánláshoz képest.

\subsection{Reanimáció abbahagyása/meg nem kezdése}

Az egészségügyi ellátórendszereknek, a klinikusoknak és a lakosságnak is kondíciófüggő beavatkozásként kell a CPR-re tekinteniük. Az egészségügynek mind intra- mind extrahospitális esetekre meg kell határozni a reanimáció meg nem kezdésének, vagy befejezhetöségének kritériumait, figyelembe véve a helyi jogi és kulturális környezetet is. A szerzők az alábbi kritériumokat ajánlják mérlegelni:

a) Egyértelmű kritériumok:

- Az ellátó biztonsága nem biztosítható megfelelöen

- Egyértelmủen halálos sérülés vagy irreverzibilis halál jelei

b) Informatív jellegủ kritériumok:

- Megfelelően kivitelezett ALS ellenére, 20 perces perzisztens aszisztólia azonosítható, reverzibilis okok hiánya mellett.

- Ismeretlen ideje bekövetkezett keringésmegállás, nem sokkolandó iniciális ritmussal, ahol a CPR megkezdése várhatóan nem jár pozitív hozadékkal (súlyos krónikus komorbiditás, rendkívül alacsony életminőség a keringésmegállást megelőzően, így például ágyhoz kötött súlyos értelmi-testi fogyatékos beteg.

- Egyéb erős bizonyíték arra vonatkozóan, hogy az újraélesztés nem állna összhangban a beteg értékrendjével és preferenciáival.

c) Önmagukban döntéshozatalra nem alkalmas kritériumok:

- Pupilla tágassága

- CPR idötartama

- $\mathrm{EtCO}_{2}$ mért értéke

- Komorbiditás
- Iniciális laktát szint

- Szuicid szándék

Fontos a beteg hozzátartozóinak bevonása az újraélesztés meg nem kezdésére, illetve abbahagyására vonatkozó döntésbe, pontos, bizonyítékokon alapuló információkat nyújtva számukra a várható kimenetellel kapcsolatban. Az anglo-amerikai szlengben „slow code"-nak nevezett, szuboptimális CPR kivitelezése (úgy téve, mintha megfelelő terápiát alkalmaznánk, pedig a beteg tudhatóan menthetetlen), etikai szempontból erősen megkérdőjelezhető, sem a hozzátartozók, sem a beteg számára nem hordoz előnyöket(34,35), így jelen ajánlás egyéb, etikailag elfogadhatóbb eljárást javasol ezekben az esetekben(36).

\section{7 Összefoglaló}

- Nem történt nagyobb változtatás a korábbi ajánláshoz képest

- A jó minőségü mellkaskompressziók, a minimalizált kompressziós szünetek és a korai defibrilláció továbbra is prioritásként kezelendőek.

- CPR alatt a légútbiztosító beavatkozásokat növekvő komplexitás szerinti sorend alapján válasszuk, a hatékony légútbiztosítás eléréséig. Ha emeltszintű légútbiztosítás válik szükségessé, csak az abban gyakorlott ellátó válassza az endotracheális intubációt. ETI szempontjából gyakorlottnak tekinthetjük azt az ellátót, aki 95\%-os valószínűséggel két próbálkozásból sikeresen végrehajtja a beavatkozást.

- Nem sokkolandó ritmus esetén azonnal, sokkolandó ritmus esetén a harmadik sokk után adjunk adrenalint.

- Az irányelv elismeri az ultrahangvizsgálat (POCUS) fokozódó szerepét a peri-arrest diagnózisalkotásban, de hangsúlyozzák, hogy ehhez képzett vizsgáló szükséges, és minimalizálni kell a mellkaskompressziós szüneteket.

- A szerzők kiemelik az eCPR hatékonyságát azokban az esetekben, amikor a standard ALS nem elég hatékony, vagy csak így juttatható el a beteg specifikus ellátás helyszínére ( $p l$. perkután koronária intervenció, pulmonális trombektómia stb.)

- Az ajánlás az európai és nemzetközi guideline-ok szerint jelölte ki a peri-arrest ellátás irányát. 


\section{Periarrest ritmuszavarok}

A kezdeti $\mathrm{ABCDE}$ betegvizsgálatot követően a célzott $\mathrm{O}_{2}$ szaturációs érték elérése (>94\%), intravénás út biztosítása (vagy azzal egyenértékü egyéb gyógyszerbejuttatási lehetőség) a teendő. A beteg monitorozása magában foglalja a vérnyomás neminvazív mérését, 12 elvezetéses EKG regisztrátum készítését, valamit az EKG görbe folyamatos megfigyelését. Fontos beazonosítani a potenciálisan reverzibilis okokat, ezt követően, amennyiben kórokként szerepelnek a ritmuszavar kialakulásában, ellátni azokat.

Az instabilitás négy tényező alapján azonosítandó, ezek a keringési shock, a syncope, a szívizomischaemia és a súlyos szívelégtelenség. Ha ezek közül bármelyik észlelhető a betegnél, úgy a beteget instabilnak kell tekinteni.

\subsection{Tachycardia}

\subsubsection{Instabil tachycardia}

Az instabilitást okozó tachyarrhythmiák ellátásának gerincét továbbra is az elektroterápia jelenti, mely iniciális ritmustól függő energiamennyiséggel, szinkronizált DC-shock leadásával kell, hogy megtörténjen, egymást követően legfeljebb három alkalommal. Amennyiben a ritmuszavar vertálódása nem érhető el, úgy gyógyszeres terápiát követő újbóli (egyszeri) szinkronizált shock alkalmazható. E hibrid cardioverzióhoz antiarrhythmias szerként intravénásan adott procainamid $(10-15 \mathrm{mg} / \mathrm{ttkg} 20$ perc alatt), vagy amiodaron (300 mg 10-20 perc alatt - a telítö dózis adása ) választható, majd ( $900 \mathrm{mg} / 24$ órás) folytatva a megkezdett terápiát.

\subsubsection{Stabil tachycardia}

Ha az instabilitás jelei közül egyik sem észlelhető, akkor az EKG görbén azonosítható kamrai komplexumok időtartamának vizsgálatával folytatódik az ellátás irányának azonosítása. Amennyiben a kamrai komplexum időtartama a 120 ms-ot meghaladja, úgy széles, ha ennél rövidebb, keskeny kamrai komplexummal járó tachycardiáról beszélünk. Ezt követően a regularitás vizsgálata következik, így különbséget tehetünk ritmusos, vagyis reguláris és irreguláris szívműködés között.

\subsubsection{Irreguláris, széles kamrai komplexumú tachycardia}

Ez esetben a protokoll két lehetséges kórokot különít el:

- Torsades de Pointes (TdP) típusú ritmuszavarral állunk szemben, mely ellátásához 10 perc alatt intravénásan beadott magnézium ajánlott ( $2 \mathrm{~g}$ dózisban), vagy

- pitvarfibrilláció aberráns (szárblokkal történő) kamrai levezetéssel, amikoris az ajánlás az irreguláris, keskeny kamrai komplexummal járó tachycardiák ellátási algoritmusának alkalmazását javasolja.

\subsubsection{Irreguláris, keskeny komplexumú tachycardia}

Ebben az esetben feltételezhetően pitvarfibrilláció áll a ritmuszavar hátterében, ekkor frekvenciakontrollt alkalmazhatunk béta-receptor blokkoló vagy diltiazem alkalmazásával. Szívelégtelenség esetén meggondolandó digoxin vagy amiodarone intravénás adagolása. Ha a ritmuszavar vélelmezhetően több, mint 48 órán túl áll fenn, a thrombembolias szövődmények kockázatának csökkentése érdekében gondoskodjunk antikoaguláns terápiáról.

\subsubsection{Reguláris tachycardia}

Abban az esetben, ha reguláris ritmus azonosítható, a kezdeti ellátási lépéseket nem befolyásolja a kamrai komplexum időtartama. Itt első lépésként vagusingerlést kell alkalmazni, a protokoll javaslata szerint lehetőleg hanyatt fekvő, emelt alsó végtagokkal történő testhelyzetben történő pozícionálást követően kerüljön sor a Valsalva manőver kivitelezésére, mely céljából szólítsuk fel a beteget, hogy egy $10 \mathrm{ml}$-es fecskendő dugattyúját próbálja meg egy levegővel kifújni. Hatástalanság esetén, amennyiben nincs tudomásunk ismert kamrai pre-excitációról, vagy a korábbi (nyugalmi) EKG-n erre utaló jelet (PR megrövidülés és delta-hullám megjelenése) nem látunk, úgy adenosin adandó, $6 \mathrm{mg}$ dózisban, proximális vénába, gyors bólus injekció formájában, bemosás mellett (rövid felezési ideje miatt), majd szükség esetén ez 12 mg-os dózisban ismételhető. Ennek hatástalansága esetén a beteg tolerábilitása, és a várható mellékhatások mérlegelését követően további 18 mg adható, szintén intravénásan, a korábban említett módon. 


\section{EREDETI KÖZLEMÉNY}

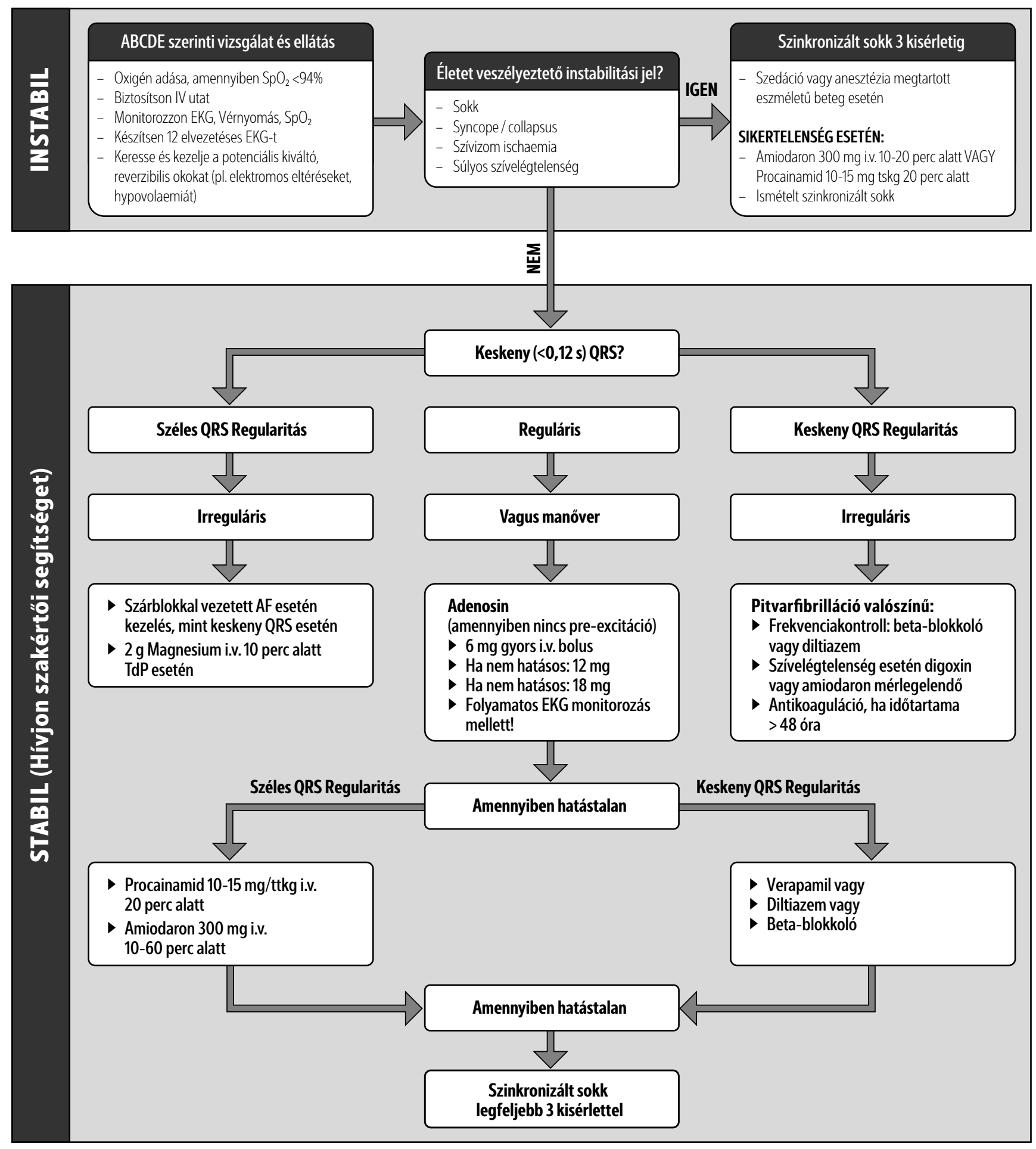

3. ábra Tachycardia ellátási algoritmusa

Amennyiben a ritmuszavar perzisztál, úgy széles kamrai komplexum esetében procainamid adható az instabil ágnak megfelelő dózisban és időtartamban, illetve amiodaron $300 \mathrm{mg}$ 10-60 perc alatti intravénás adagolása mellett is dönthetünk, melyet követően az instabil ágon már említett telítő dózist is alkalmazni szükséges. Ha a kamrai komplexum időtartama nem haladja meg a $120 \mathrm{~ms}$-ot, úgy verapamil, diltiazem vagy béta-receptor blokkoló adható, ajánlás szerinti módon és dózisban. 
Amennyiben az alkalmazott kezelés továbbra sem vezet célra, úgy a protokoll a korábbi, 2015-ös ajánlásban még nem említett, háromszori szinkronizált DC shock leadását javasolja (1)

\subsection{Bradycardia (4. ábra)}

A beteg elsődleges vizsgálata, illetve az instabilitás értékelése megegyezik a tachycardia algoritmusban feltüntetett ajánlásokkal. Az ABCDE betegvizsgálat után shock, syncope, súlyos szívelégtelenség és szívizomischaemia jeleit keressük.

\subsubsection{Instabil bradycardia}

Amennyiben a fenti instabilitási jelek bármelyikét észleljük, úgy a protokollban ajánlott első vonalbeli gyógyszer, az atropin egyszeri $500 \mu \mathrm{g}$ iv adását követően figyeljük a betegünk állapotváltozását, illetve His-Purkinje szint alatti területről származó ingerképzés esetén előkészülünk transcutan pacemaker terápiához. Az atropinkezelésre adott nem kielégítő reakció esetén a következő beavatkozási lehetőségek közül választhatunk: a megkezdett atropine 500 $\mu$ g-onkénti adagolása maximum 3 mg összdózisig,

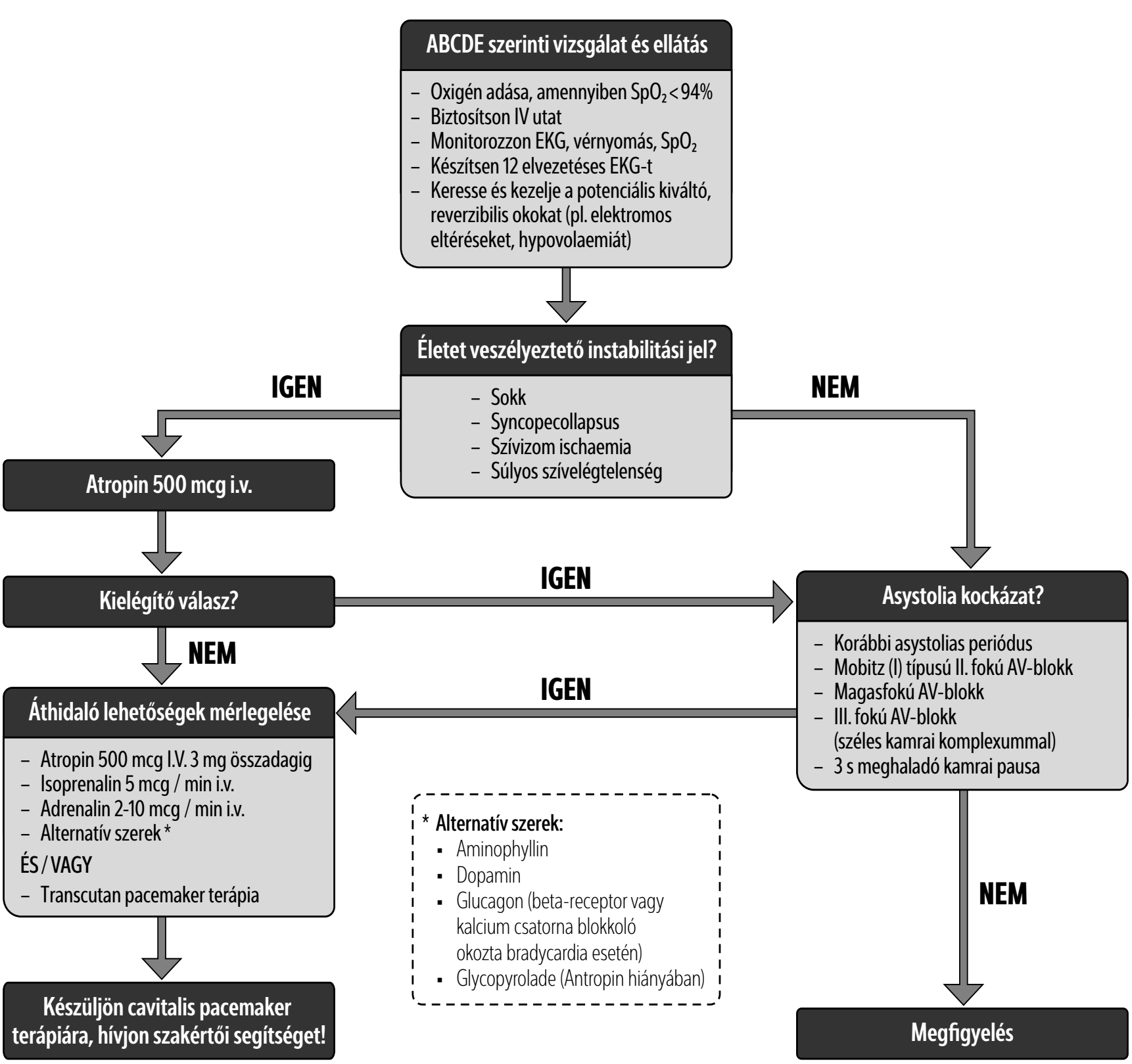

4. ábra: A bradycardia ellátási algoritmusa 
ennek hatástalansága esetén második vonalbeli gyógyszerek alkalmazhatóak (így adrenalin $2-10 \mu \mathrm{g} / \mathrm{min}$ adagolásban, illetve az isoprenalin $5 \mu \mathrm{g} / \mathrm{min}$ kezdődózisban). Ezek mellett, vagy ezek helyett indokolt esetben transcutan pacemaker ingerlést lehet alkalmazni.

Bizonyos esetek fennállásakor az ajánlott szerek, illetve beavatkozások nem alkalmazhatóak vagy nem hoznának eredményt. Ilyenkor alternatív szerek választhatóak a körülményekhez igazítottan. Amennyiben a bradycardiát jobb kamrát érintő infarktus, vagy gerincvelö sérülés okozza, esetleg ismert szívtranszplantáción átesett beteg az ellátandó, úgy aminophyllin 100-200 mg adandó lassú intravénás injekcióként. Fontos tudni, hogy szívtranszplantáció esetében rendkívül fontos az atropin kerülése, mivel magasfokú AV blokkot, vagy sinus arrest-et indikálhat. Béta-receptor blokkoló, illetve kalcium-csatorna blokkoló mérgezett beteg esetében megfontolandó glucagon intravénás adagolása a tünetekhez igazítottan. Egyéb alternatív gyógyszerként felmerülhet a glycopyrollat vagy dopamin alkalmazása.

Ha a fenti lehetőségek ellenére is perzisztál a bradycardia, úgy kérjünk szakértői segítséget és készüljünk intracavitális pacemaker terápiához.

Amennyiben életet veszélyeztető instabilitási jelek nem észlelhetőek, vagy ha az instabil ágon alkalmazott atropin első dózisa kielégítő választ hoz, akkor az aszisztólia kockázatát kell mérlegelnünk. Keressük a korábban fennálló aszisztóliás periódusokat, Mobitz II típusú másodfokú, magasfokú, illetve harmadfokú AV blokkot a 12 elvezetéses EKG regisztrátumon, illetve EKG monitorizálás közben észlelhető 3 másodpercet meghaladó kamrai pauzát. Aszisztólia kockázatának azonosítása esetén térjünk vissza az instabil ágra, és válasszunk gyógyszeres, vagy elektroterápiát. Ha aszisztólia veszélye nem merül fel, úgy a beteget a továbbiakban megfigyeljük.

\subsection{Főbb változások}

\subsubsection{Elektroterápia}

Pár fontosabb változás történt az elektroterápiában a szinkronizált kardioverziót illetően. A korábbi protokollban meghatározásra került, hogy keskeny QRS tachycardiák esetén (nevesítve: pitvari flattern és paroxizmális szupraventrikuláris tachycardia), bifázisos defibrillátorral végzett kardióverziónál az alacsonyabb kezdő energia preferálandó. 70-120 J-ról indulva, emelkedő energiaértékekkel kell a kardioverziót végezni (37). A 2015-ös ajánlásban pulzussal járó kamrai tachycardia és pitvarfibrilláció megszüntetésére 120-150 J volt a javasolt kezdő energia dózis (2). Változás történt a pitvarfibrilláció kardioverziójára vonatkozóan is. A ERC 276 fó bevonásával készült randomizált kutatásának eredményei alapján ezen ritmuszavar esetén az elérhető legmagasabb energiaértékről (a studyban $360 \mathrm{~J}$ ) kell indítani a terápiát, bifázisos készülék esetén. (38)

Kiemelendő továbbá, hogy mivel a kamrai tachycardia szerteágazó morfológiai képpel megjelenni képes ritmuszavar, ezért esetenként az elektroterápiás eszközzel történő szikronizálása problémába ütközhet. Az ajánlás a defibrillátor készülék sikertelen szinkronizációjakor, instabilitás jeleit mutató beteg esetén (kamrai tachycardia EKG képével), a sinus ritmus mihamarabbi visszaállításának időintervallumát lerövidítendő, aszinkron üzemmódban javasolja a shockok leadását (1).

\subsubsection{Gyógyszeres terápia}

Több változás is történt a korábbi ERC ajánláshoz képest, új gyógyszerek kerültek a guideline-ba, illetve dózismódosításra is sor került. A 2021-es protokollban a preexcitációs szindrómák a stabil tachycardiák ellátásánál jelennek meg említés szintjén. További ellátási irányként a European Society of Cardiology (ESC) és az American Heart Association (AHA) ajánlásait hivatkozzák $(39,40),(41)$, így a továbbiakban az ebben foglaltak figyelembevételével mutatjuk be a helyes terápiaválasztás folyamatát.

Instabil beteg ellátása során, amennyiben sikertelen a kardióverziós kísérlet, úgy az úgynevezett hibrid cardioversio kivitelezhető. Ezen eljárás részeként az antiarrythmicumként használt amiodaron mellett megjelenik a procainamid, a már korábban ismertetett dózisban. Randomizált vizsgálatok során úgy találták, hogy az ismeretlen etiológiájú széles kamrai komplexumú tachycardiák esetén a procainamid ritkábban okozott a keringési rendszert érintő mellékhatást, illetve gyakrabban terminálta a pathológiás ritmust, mint az 
amiodaron (42). Ezen megfontolásból került be a reguláris széles kamrai komplexumú tachycardiák ellátásába is, azonban ez jelenleg sok országban nem érhető el.

Fontos megjegyezni, hogy amint a korábbiakban már leírásra került, a reguláris tachyarrhytmiák ellátása egy ággá egyesült, és a kezdeti manuális és gyógyszeres terápiák elvégzése még független a kamrai depolarizáció elektromos tevékenységét jellemző kamrai komplexum időtartamától. Pontosan meghatározásra került a vagus manőver kivitelezésének technikája, melynek hatástalansága esetén a 2015-ös ajánlásban már leírt reguláris keskeny kamrai komplexumú tachycardia algoritmusban is használt adenosin adagolása a választandó, emelkedő dózisban, azonban a korábbiakkal ellentétben a harmadik bólus $12 \mathrm{mg}$ helyett $18 \mathrm{mg}$-ra, azaz a kezdődózis háromszorosára emelkedett.

\subsubsection{Preexcitációs kórfolyamatok}

Ellátási nehézséget okozhat, hogy szemben az ESCAHA közös ajánlással, sem a folyamatábra, sem maga a protokoll nem tér ki a preexcitáció okozta ritmuszavarok kérdésére. A guideline-ban a reguláris tachycardiák ellátásánál jelenik csak meg, illetve a protokoll kiköti, hogy ezen ritmus megléte esetén adenozin alkalmazása kerülendő. A peri-arrest ritmuszavarok ellátásával kapcsolatban a szerzők az AHA illetve az ESC ajánlásait
(39),(41) jelölik követendőnek, amiben már fellelhetőek ezen típusú ritmusokra alkalmazható konkrét ajánlások is. Fontos megjegyezni, hogy a preexcitáció meglétét alapvetően anamnézis vagy nyugalmi EKG-n látható diagnosztikus jelek alapján kell megállapítanunk (PR szakasz megrövidülése, kamrai komplexum delta-hullámmal történő kiszélesedése), mert tachyarrithmiák esetén gyakran nem detektálhatóak.

Bár a preexcitációs szindrómák nem minden esetben szélesítik ki 120 ms mértékig a kamrai komplexumot, a protokoll mégis a széles reguláris QRS tachyarrithmiák ellátási vonalán vezeti a gyógyszeres terápiájukat, mivel keskeny kamrai komplexummal járó tachycardiák ellátási algoritmus választása esetén a javasolt gyógyszerek mindegyike kamrafibrillációt generálhat ezeknél a ritmuszavaroknál. Kiemelnénk azonban azt is, hogy a fent említett ajánlott terápia esetében felmerült az amiodaron proarritmiás hatásának veszélye is, ezért a procaninamid-ot tartják biztonságosabb szernek.

Szintén megemlítendő, hogy bár az ERC protokoll nem jegyzi az irreguláris széles kamrai komplexumú tachyarrithmiák közt a preexcitációs szindróma mellett fennálló pitvarfibrilláció esetét, az ESC itt is pontos ajánlást tesz, miszerint ebben az esetben ibutilid vagy procainamid (IIa B), illetve flecainid vagy propafenon (IIb B) a javasolt gyógyszerek (39) (5. ábra)

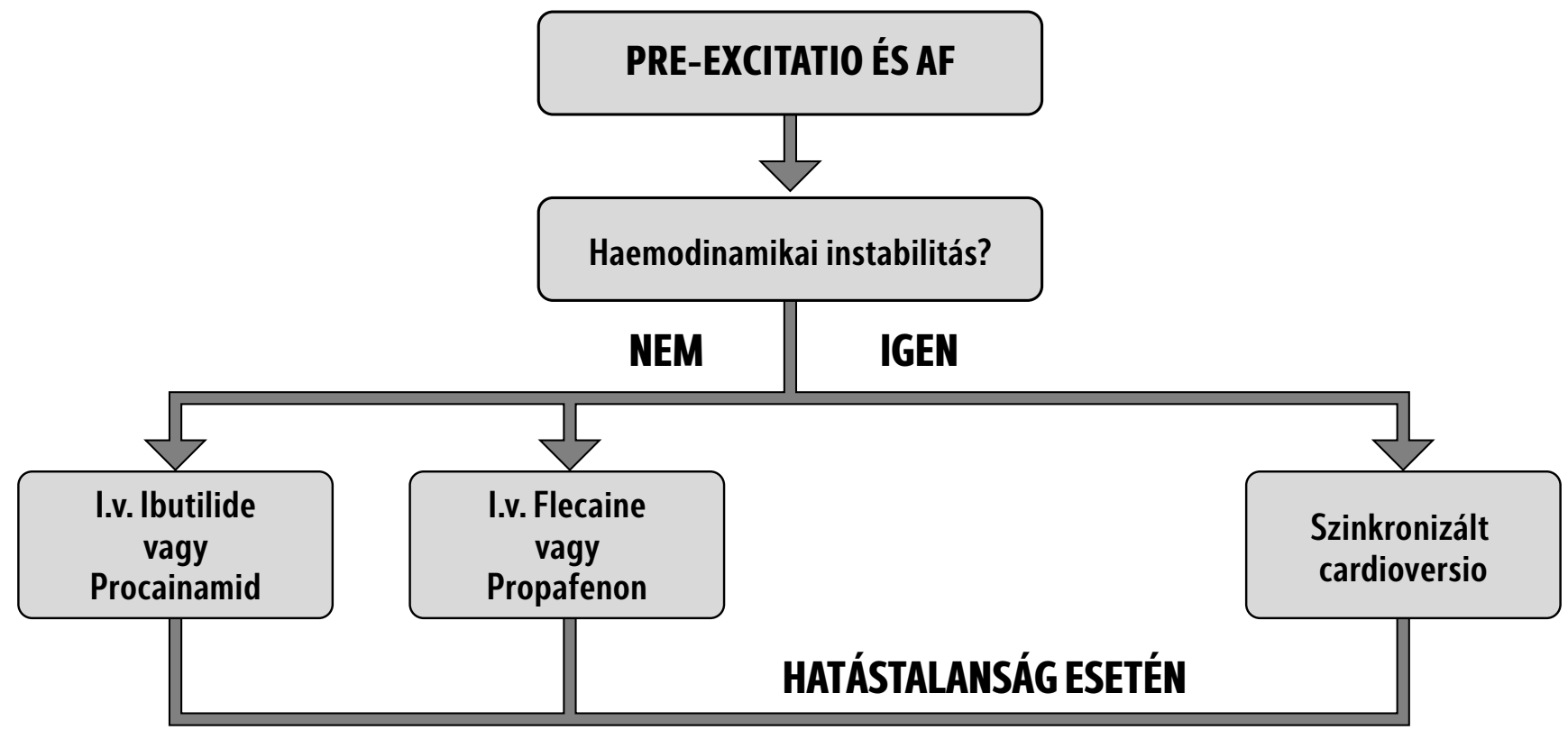

5. ábra: Pre-excitatio és pitvarfibrilláció ellátási algoritmusa 


\section{Irodalomjegyzék}

1. SoarJ, Böttiger BW, Carli P, et al. European Resuscitation Council Guidelines 2021: Adult advanced life support. Resuscitation. 2021;161:115-51.

2. Soar J, Nolan JP, Böttiger BW, et al. European Resuscitation Council Guidelines for Resuscitation 2015. Section 3. Adult advanced life support. Resuscitation. 2015;95:100-47.

3. Soar J, Berg KM, Andersen LW, et al. Adult Advanced Life Support: 2020 International Consensus on Cardiopulmonary Resuscitation and Emergency Cardiovascular Care Science with Treatment Recommendations. Resuscitation. 2020;156:A80-119.

4. Lederman Z. A critique of the recent 2018 ERC CPR guidelines. Resuscitation [Internet]. 2019;139:367. Available from: https://doi.org/10.1016/j. resuscitation.2018.12.024

5. Nolan JP, Sandroni C, Böttiger BW, et al. European Resuscitation Council and European Society of Intensive Care Medicine Guidelines 2021: Postresuscitation care. Resuscitation [Internet]. 2021 Apr 1 [cited 2021 Apr 12];161:220-69. Available from: https://linkinghub.elsevier.com/retrieve/pii/ S0300957221000654

6. Nichol G, Leroux B, Wang H, et al. Trial of Continuous or Interrupted Chest Compressions during CPR. N Engl J Med. 2015;373(23):2203-14.

7. Olasveengen TM, de Caen AR, Mancini ME, et al. 2017 International Consensus on Cardiopulmonary Resuscitation and Emergency Cardiovascular Care Science With Treatment Recommendations Summary. Resuscitation [Internet]. 2017;121:20114. Available from: http://dx.doi.org/10.1016/j. resuscitation.2017.10.021

8. Benger JR, Kirby K, Black S, et al. Effect of a strategy of a supraglottic airway device vs tracheal intubation during out-of-hospital cardiac arrest on functional outcome the AIRWAYS-2 randomized clinical trial. JAMA - J Am Med Assoc. 2018;320(8):779-91.

9. Cook TM, Boniface NJ, Seller C, et al. Universal videolaryngoscopy: a structured approach to conversion to videolaryngoscopy for all intubations in an anaesthetic and intensive care department. Br J Anaesth [Internet]. 2018;120(1):173-80. Available from: https://doi.org/10.1016/j.bja.2017.11.014

10. Goto Y, Goto T, Hagiwara Y, et al. Techniques and outcomes of emergency airway management in
Japan: An analysis of two multicentre prospective observational studies, 2010-2016. Resuscitation [Internet]. 2017;114:14-20. Available from: http:// dx.doi.org/10.1016/j.resuscitation.2017.02.009

11. Lee DH, Han M, An JY, et al. Video laryngoscopy versus direct laryngoscopy for tracheal intubation during in-hospital cardiopulmonary resuscitation. Resuscitation [Internet]. 2015;89(C):195-9. Available from: http://dx.doi.org/10.1016/j. resuscitation.2014.11.030

12. Park SO, Kim JW, Na JH, et al. Video laryngoscopy improves the first-attempt success in endotracheal intubation during cardiopulmonary resuscitation among novice physicians. Resuscitation [Internet]. 2015;89(C):188-94. Available from: http://dx.doi. org/10.1016/j.resuscitation.2014.12.010

13. Jiang J, Kang N, Li B, et al. Comparison of adverse events between video and direct laryngoscopes for tracheal intubations in emergency department and ICU patients-a systematic review and meta-analysis. Scand J Trauma Resusc Emerg Med. 2020;28(1):1-14.

14. Kim JW, Park SO, Lee KR, et al. Video laryngoscopy vs. direct laryngoscopy: Which should be chosen for endotracheal intubation during cardiopulmonary resuscitation? A prospective randomized controlled study of experienced intubators. Resuscitation [Internet]. 2016;105:196-202. Available from: http:// dx.doi.org/10.1016/j.resuscitation.2016.04.003

15. Paiva EF, Paxton JH, O’Neil BJ. The use of end-tidal carbon dioxide $\left(\mathrm{ETCO}_{2}\right)$ measurement to guide management of cardiac arrest: A systematic review. Resuscitation [Internet]. 2018;123:1-7. Available from: http://dx.doi.org/10.1016/j.resuscitation.2017.12.003

16. Sandroni C, De Santis P, D’Arrigo S. Capnography during cardiac arrest. Resuscitation [Internet]. 2018;132(July):73-7. Available from: https://doi. org/10.1016/j.resuscitation.2018.08.018

17. Gutiérrez JJ, Ruiz JM, de Gauna SR, et al. Modeling the impact of ventilations on the capnogram in out-ofhospital cardiac arrest. PLoS One. 2020;15(2):1-15.

18. Callaway CW, Soar J, Aibiki M, et al. Part 4: Advanced life support: 2015 International consensus on cardiopulmonary resuscitation and emergency cardiovascular care science with treatment recommendations. Vol. 132, Circulation. 2015. 84-145 p. 
19. Hamrick JL, Hamrick JT, Lee JK, et al. Efficacy of chest compressions directed by end-tidal $\mathrm{CO}_{2}$ feedback in a pediatric resuscitation model of basic life support. J Am Heart Assoc. 2014;3(2):1-12.

20. Garnett AR, Ornato JP, Gonzalez ER, et al. End-Tidal Carbon Dioxide Monitoring During Cardiopulmonary Resuscitation. JAMA J Am Med Assoc. 1987;257(4):512-5.

21. Sutton RM, French B, Meaney PA, et al. Physiologic monitoring of $\mathrm{CPR}$ quality during adult cardiac arrest: A propensity-matched cohort study. Resuscitation [Internet]. 2016;106:76-82. Available from: http:// dx.doi.org/10.1016/j.resuscitation.2016.06.018

22. Robert L L, Marvin A W, Charles C M. End -tidal carbondioxid and outcome of out-of-hospital cardiac arrest. N Engl J Med. :301-6.

23. Lott C, Truhlár A, Alfonzo A, et al. European Resuscitation Council Guidelines 2021: Cardiac arrest in special circumstances. Resuscitation. 2021 Apr;161:152-219.

24. Blanco P, Volpicelli G. Common pitfalls in point - of - care ultrasound : a practical guide for emergency and critical care physicians. Crit Ultrasound J. 2016;

25. Bessereau J, Querellou E, Leyral J, et al.`t cardiaque intra- et extrahospitalier : mise au point et perspectives. 2009;28:769-78.

26. Berg RA, Sorrell VL, Kern KB, et al. Overdistention Without Left Ventricular Volume Loss. 2015; L:1136-41.

27. Dickinson ET, Verdile VP, Schneider RM, et al. Effectiveness of Mechanical Versus Manual Chest Compressions in Out-of-Hospital Cardiac Arrest Resuscitation : A Pilot Study. 1994;289-92.

28. Perkins GD, Lall R, Quinn T, et al. Mechanical versus manual chest compression for out-of-hospital cardiac arrest ( PARAMEDIC ): a pragmatic, cluster randomised controlled trial. :947-55.

29. Rubertsson S, Lindgren E, Smekal D, et al. Mechanical Chest Compressions and Simultaneous Defibrillation vs Conventional Cardiopulmonary Resuscitation in Outof-Hospital Cardiac Arrest The LINC Randomized Trial. 2015;311(1):53-61.

30. Smekal D, Johansson J, Huzevka T, et al. Clinical paper A pilot study of mechanical chest compressions with the
LUCAS TM device in cardiopulmonary resuscitation $₫$. 2011;82:702-6.

31. Trial AR, Hallstrom A, Rea TD, et al. Manual Chest Compression vs Use of an. 2015;295(22).

32. Wik L, Olsen J, Persse D, et al. Manual vs . integrated automatic load-distributing band CPR with equal survival after out of hospital cardiac arrest. The randomized. Resuscitation [Internet]. 2014;85(6): 741-8. Available from: http://dx.doi.org/10.1016/j. resuscitation.2014.03.005

33. Richardson ASC, Tonna JE, Nanjayya V, et al. Extracorporeal Cardiopulmonary Resuscitation in Adults. Interim Guideline Consensus Statement From the Extracorporeal Life Support Organization. ASAIO J. 2021;67(3):221-8.

34. Kelly J. Nurses' and doctors' perspectives on slow codes. Nurs Ethics. 2008;15(1):110-20.

35. Kelly J. Literature review: Decision-making regarding slow resuscitation. J Clin Nurs. 2007;16(11):1989-96.

36. Roth A, Elkayam I, Shapira I, et al. Effectiveness of prehospital synchronous direct-current cardioversion for supraventricular tachyarrhythmias causing unstable hemodynamic states. AmJ Cardiol. 2003;91(4):489-91.

37. Schmidt AS, Lauridsen KG, Torp P, et al. Maximumfixed energy shocks for cardioverting atrial fibrillation. Eur Heart J. 2020;41(5):626-31.

38. Brugada J, Katritsis DG, Arbelo E, et al. 2019 ESC Guidelines for themanagement of patients with supraventricular tachycardia. Eur Heart J [Internet]. 2020 Feb 1 [cited 2021 Apr 7];41(5):655-720. Available from: www.escardio.org/guidelines

39. Panchal AR, Bartos JA, Cabañas JG, et al. Part 3: Adult Basic and Advanced Life Support: 2020 American Heart Association Guidelines for Cardiopulmonary Resuscitation and Emergency Cardiovascular Care. Vol. 142, Circulation. 2020.366-468 p.

40. Ortiz M, Martin A, Arribas F, et al. Randomized comparison of intravenous procainamide vs. intravenous amiodarone for the acute treatment of tolerated wide QRS tachycardia: The PROCAMIO study. Eur Heart J. 2017;38(17):1329-35. 